\title{
EVENTS OF BILINGUISM AND INTERFERENCE
}

\author{
Mukhammad Khodjakhonovich Khakimov
}

Doctor Of Philological Sciences, Professor Of Fergana State University, Uzbekistan

Yokuthon Nurmatovna Yormatova

Lecturer,The Regional Center For Retraining And Upgrading Of Public Education Of Ferghana Region,

Independent Researcher Of Fergana State University, Uzbekistan Fergana City

\section{ABSTRACT}

The article gives an idea of the phenomenon of interference and its specificity, the different assessments of this phenomenon by linguists. Feedback and conclusions on the study of the phenomenon of interference in the context of multilingualism at the language level and the formation of new areas are presented.

KEYWORDS: - Interference phenomenon, bilingualism, speech intonation, interference concepts, language levels.

\section{INTRODUCTION}

Today, in the context of the intensification of processes between different cultures, globalization and the digital economy, the problems of language communication and issues aimed at their solution are gaining particular relevance. Especially in the study of interference issues, issues related to speech intonation play an important role in revealing the essence of direction.

\section{THE MAIN PART}

The concepts of "interference", "bilingualism" and "polylingualism" are one of the main categories of the theory of language contacts in linguistics. Linguists associate the emergence of bilingualism with a primitive community system.[1] Scientists have for the first time been able to identify the phenomenon of bilingualism in the language of members of the Sumerian tribe living in Mesopotamia. In 2000 BC, the Sumerians were occupied by the Akkadians, and for them the Sumerian language remained the second and most sacred language. Here the Akkadians began to communicate in both languages, resulting in the concepts of bilingualism and native language. In the process of paying attention and studying these issues, knowledge and skills in this field began to be formed. This led to the emergence of monolingual and bilingual dictionaries for the first time in Mesopotamia. Bilingual dictionaries also played an important role in the language teaching process in Ancient Babylon.

Since the middle of the last century, research on the phenomenon of bilingualism in world and Russian 
CURRENT RESEARCH JOURNAL OF PHILOLOGICAL SCIENCES 2(8): 31-35,

May 2021 DOI: https://doi.org/10.37547/philological-crjps-02-08-08

ISSN 2767-3758

(C)2021 Master Journals

Crossref do: 81 Google

Accepted25thAugust, 2021 \& Published $30^{\text {th }}$ August, 2021

linguistics has been reflected in the research of linguists such as U. Weinreich, S. Ervin and Ch. Osgud, L.V.Shcherba.

Issues of bilingualism are studied in the sociolinguistic direction of linguistics. That is why research on bilingualism, multilingualism, is unique in that its authors have their own views in the field of sociolinguistics. The term bilingualism is defined in terminological dictionaries as follows: "... the use of multiple languages by individuals or groups of people based on a real communicative situation." [2]

In one of his works, Y.D. Desheriev describes bilingualism as "the ability to speak two languages fluently." And V.A Avrorin understands bilingualism as "approximately the same free mastery of two languages." Also, the phenomena of bilingualism and polylingualism are one of the characteristic features of the modern world of linguistics. Also, the scientist points out that the phenomena of bilingualism and polylingualism are one of the characteristic features of the current world of linguistics, and intensive relations between countries and communication between people in developed modern conditions "without the presence of a phenomenon of duality in a certain layer of the population, it was impossible to imagine the interaction of mutual interests of Nations, peoples in political, economic and cultural spheres."

A gradual-descriptive definition of bilingualism can be found in the works of W. Weinreich, who called "... the practice of alternating use of two languages is bilingualism, and those who practice it are bilingual." [3]

One of the supporters of W. Weinreich's views on bilingualism is the well-known Russian linguist V. Y. Rosentsweig. He also emphasizes that "the concept of bilingualism is understood as the regular transition from one language to another, based on the state of bilingualism and communication."[4]
Bilingualism is the ability to communicate fluently in two languages and to be bilingual. Bilinguals are people who communicate in two languages.

Linguists J.Bagana and E.V.Khapilina in their monographs have defined the concept of bilingualism in a narrow and wide range. [5] Most linguists are more open to a broader definition: "... bilingualism is always interpreted as the transition from one language code to another in a particular context of communication." The American linguist L. Bloomfield described bilingualism as the phenomenon of a person's perfect mastery of both his native language and a foreign language. [6] E. Haugen, one of the well-known founders of the theory of language contacts, disagreed with the opinion of the American linguist L. Bloomfield and argued that in the phenomenon of bilingualism the possession of one language should be much lower than that of another. [7]

In our opinion, it is possible to rely more on E. Haugen's views on the phenomenon of bilingualism than on the above opinions of other linguists. Indeed, a person cannot master a foreign language perfectly at the level of his native language, and the foreign language he has mastered will always be at a lower level than the level of his native language. This results in pronunciation based on phonetic, lexical-semantic, and grammatical features related to language levels between the two languages. This is called the term interference in linguistics. Research on the concepts of "interference", "bilingualism" and "polylingualism" has been reflected in the scientific work and research of many scholars, such as Baudouin de Courtenay, R.O. Jacobson, N.S. Trubetskoy, L.V. Shcherba, E.Xaugen, E.D.Polivanov, U.Vaynrayx, A.E.Karlinskiy, E.M.Vereshchagin, V.Yu.Rozentsveyg, V.A.Bogoroditskiy, S.I.Bernshteyn, A.A. Reformatskiy, V.A.Avrorin, Yu.D.Desheriev, V.V.Vinogradov, M.K.Isaev, G.N.Lebedeva, N.A.Lyubimova, A.A.Metlyuk. 
CURRENT RESEARCH JOURNAL OF PHILOLOGICAL SCIENCES 2(8): 31-35,

May 2021 DOI: https://doi.org/10.37547/philological-crjps-02-08-08

ISSN 2767-3758

(C)2021 Master Journals

Crossref do: 81 Google

Accepted25thAugust, 2021 \& Published 30th August, 2021

The term "interference" is derived from Latin, meaning "inter" - mutual, "ferens (ferentis)" carrier.[8] That is, language interference is the involuntary use of native language features in a second language.[9] In addition to this definition of the phenomenon of interference, it should be noted that in the process of communicating in another language, the speakers do not involuntarily, but communicate at the level of knowledge, skills, abilities. Perfect knowledge of another language also leads to the expression of linguocultural features. Therefore, the issue of approach to the concept of interference serves as a basis for elucidating the essence of this concept.

The phenomenon of "interference" has long been of interest to many scholars in world linguistics. For the first time, the idea of the interaction of languages belonged to the linguist Baudouin de Courtenay, although the term "interference" was not yet widely used at that time, the scientist defined the term as the result of the state of interaction of languages not only with the acquisition of individual linguistic units, but also with the mutual convergence of languages as a whole. [10]

The above ideas have been further explored in L.V. Shcherba's scientific research. The scientist's views served to study and describe the concepts of interference in language. He argues that the interaction of languages results in changes in the norms of both languages that come into contact as a result.17 This, of course, happens naturally. Noncompliance with certain language norms has a negative impact on the consistent expression of thought in the process of information exchange. [11]

Later, this concept began to appear in the publications of the Prague Linguistic Circle (19261953). The popularity of the book "Language Contacts" by linguist W. Weinreich served as a basis for the spread of the theory of interference and the creation of a solid foundation for this theory. The scientist has expressed many of his views on the phenomenon of interference in language and speech of a bilingual individual. "Interference in speech is like sand moving along a stream, and interference in language can be compared to sand falling to the bottom of a lake." A closer, but slightly broader, definition of the term interference can be found in the linguistic encyclopedia compiled by V.N. Yartseva in 2002: Interference is the result of the interaction of language systems in the context of bilingualism (Latin bi- "two" + Latin lingua "language" bilingualism and the ability to communicate in these languages), in this process, either languages are described as interacting or manifested in the individual mastery of a foreign language; under the influence of language finds its expression in the violation of norms in the second language system. From the definition of the term interference in this dictionary, it is clear that it implies not only the situation that arises from the interaction of languages, but also the individual's independent learning of a foreign language.

There are many concepts today to differentiate the concept of interference, while some scholars consider the violation of language norms, existing rules and errors in the speech of foreign speakers as interference, and other linguists consider interference to be a process that reflects the interactions of languages in different systems.

A.Dibold described interference as a change in language as a result of two languages coming into contact. Ch. Hocket, on the other hand, considers interference to be an individual effect of mastery.

However, some linguists, including E.M. Vershchagin, disagree with the above view and do not believe that there is a connection between the phenomenon of interference and the violation of norms in foreign language speech. In their view, the sphere of action of interference is only the language system. The scientist suggests that interference is the phenomenon of mental interference in speech, that is, 
CURRENT RESEARCH JOURNAL OF PHILOLOGICAL SCIENCES 2(8): 31-35,

May 2021 DOI: https://doi.org/10.37547/philological-crjps-02-08-08

ISSN 2767-3758

(C)2021 Master Journals

Crossref doi) 81 Google

Accepted25thAugust, 2021 \& Published $30^{\text {th }}$ August, 2021

the manifestation of speech expression formed as a result of the interaction of skills and abilities inherent in bilingualism.[12]

Linguist VV Klimov, continuing the views of $\mathrm{U}$. Weinreich, explains that interference is a phenomenon of overlap of two language systems in the speech process.

L.I. Barannikova, in turn, considers interference as a change in the structure of one language and its elements under the influence of another language.

N.B. Mechkovskaya, on the one hand, called the interference of a person's speech in a foreign language as a result of the influence of his native language system, A.A. Reformatsky, on the other hand, believes that the reason for the appearance of interference is not the acquisition of a foreign language, but the struggle with the native language. Because the native language is in active contact with the newly emerging system of articulatory movements, says the scientist.

Another linguist, V.A. Vinogradov, said that interference occurs when bilingual language systems come into contact with each other in a bilingual environment or in the process of learning a foreign language individually, it is a phenomenon of distortion as a result of the influence of the mother tongue on the foreign language system and norms.

In his book "Problems of interference in translation" V.V. Alimov draws attention to the fact that the phenomenon of interference is not seen as a mediating activity, but as a linguistic phenomenon as a language contact for many years.

In general, the interference and the descriptions given to it can lead to a violation of its language norms and norms in the system, which, in turn, can lead to negative opinions about it.

But not all research scientists accept the phenomenon of interference as a negative concept or phenomenon. For example, the term interference is widely used to refer to "the interaction of languages in all their forms and manifestations: from the renewal of language elements to its gradual extrusion factors, it is expedient to understand the phenomenon of interference as a positive phenomenon, or in other words, a positive phenomenon that helps to enrich the languages in contact."[13]

Thus, in the absence of a single definition of the concept of "interference" in dentistry, it can be considered as a process of learning a foreign language as a result of the transfer of rigid and communicative speech skills from one language to another (from one native language to another, from one foreign language to another). The lack of uniformity in definitions is due, on the one hand, to the diversity of situations in the manifestation of language relations, the difficulty of distinguishing psychological and linguistic aspects of speech, and the other side to the fact that it is not studied experimentally and requires a complete solution, says linguist E.M. Vershchagin.[14]

\section{Conclusion}

The phenomenon of interference is related to the issues of linguistic theory as a specific new direction. In this sense, this phenomenon is considered by some linguists as a positive phenomenon and by other linguists as a negative phenomenon. There is a growing need to study the phenomenon of interference in multilingualism. The study and research of this issue in terms of language levels will lead to the emergence of new directions in linguistics.

\section{REFERENCES}

1. Mixailov, M.M. Dvuyazichie v sovremennom mire.Tekst.: kurs lektsiy / M.M.Mixailov. 
CURRENT RESEARCH JOURNAL OF PHILOLOGICAL SCIENCES 2(8): 31-35,

May 2021 DOI: https://doi.org/10.37547/philological-crjps-02-08-08

ISSN 2767-3758

(C)2021 Master Journals

Crossref do) 81 Google

Accepted25thAugust, 2021 \& Published $30^{\text {th }}$ August, 2021

CHeboksari: Izd-vo CHTU, 1988.-35 s.

2. Lingvisticheskiy entsiklopedicheskiy slovar. -

M.: Bolshaya Rossiyskaya entsiklopediya,

2002. - S.136

3. Vaynrayx U. Yazikovie kontakti. - Kiev:

Vishaya shkola, 1979. - S.22.

4. Rozentsveyg V.Yu. Yazikovie kontakti. Leningrad: Nauka, 1972. - S.4.

5. Bagana, Jerom. Kontaktnaya lingvistika. Vzaimodeystvie yazikov i bilingvizm : monografiya / J.Bagana, Ye. V. Xapilina. - 2-e izd., ster. - Moskva : Flinta, 2016. - 123, [1] s. Bibliogr.: s. 110-124

6. Blumfild L. Yazik. - M.: Progress, 1968. - 607 S.

7. Xaugen, E. Yazikovoy kontakt Tekst. / E. Xaugen // Novoe v lingvistike. M., 1972. Vip.VI. - S. 61-80.

8. Slovar inostrannix slov: [ svishe 21000 slov/otv.red.: V.V.Burtseva, N.M.Semenova]. 4-e izd., ster. - Moskva: Russkiy yazik Media, 2007 [t.e. 2006]. - 817,[2] s.

9. Zokirov M.T. Lingvistik interferentsiya va uning o'zbek - tojik bilingvizmida namoyon bo'lishi. Dis. F.f.n.- Toshkent:2007. - B.11-12.

10. Boduen de Kurtene I.A. Fonologiya. Izbrannie trudi po obshemu yazikoznaniyu. - M.: Izd-vo AN SSSR, 1963. str. 317.

11. Scherba L.V. O ponyatii smesheniy yazikov. Izbrannie raboti po yazikoznaniyu i fonetike.

- L., 1958. - str. 42-46.

12. Verschagin Ye.M. Psixologicheskaya i metodicheskaya xarakteristika dvuyazichiya (bilingvizma). - M.: Izd.vo Mosk. un-ta, 2014. $-160 \mathrm{~s}$.

13. Shomova D.Z. Yavlenie interferentsii rodnogo i russkogo yazikov pri kontakte $\mathrm{s}$ inostrannim yazikom // Vestn.Yugorskogo gos.un-ta.2010.Vip. 3 (18). S. 35-40.

14. Verschagin Ye.M. Psixologicheskaya i metodicheskaya xarakteristika dvuyazichiya (bilingvizma). - M.: Izd.vo Mosk. un-ta, 2014. $-160 \mathrm{~s}$. 